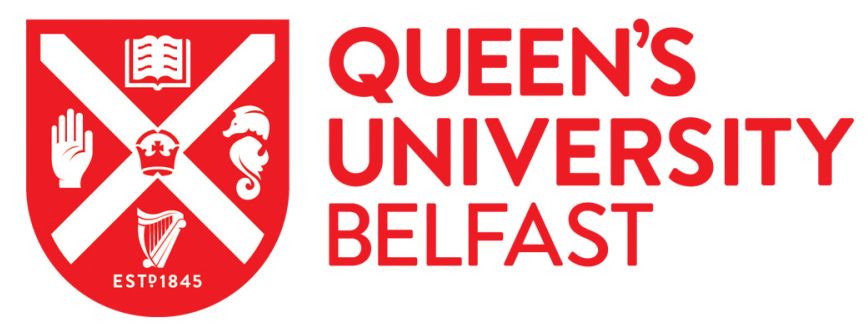

\title{
THE WOMAN TO THE PLOW; AND THE MAN TO THE HEN- ROOST: WIVES, HUSBANDS AND BEST-SELLING BALLADS IN SEVENTEENTH-CENTURY ENGLAND
}

Marsh, C. (2018). THE WOMAN TO THE PLOW; AND THE MAN TO THE HEN-ROOST: WIVES, HUSBANDS AND BEST-SELLING BALLADS IN SEVENTEENTH-CENTURY ENGLAND. Transactions of the Royal Historical Society, 28, 65-88. https://doi.org/10.1017/S008044011800004X

Published in:

Transactions of the Royal Historical Society

Document Version:

Peer reviewed version

Queen's University Belfast - Research Portal:

Link to publication record in Queen's University Belfast Research Portal

\section{Publisher rights}

Copyright Royal Historical Society 2018

This is an open access article published under a Creative Commons Attribution-NonCommercial

NoDerivsLicense(https://creativecommons.org/licenses/by-nc-nd/4.0/), which permits distribution and reproduction for non-commercial purposes, provided the author and source are cited.

\section{General rights}

Copyright for the publications made accessible via the Queen's University Belfast Research Portal is retained by the author(s) and / or other copyright owners and it is a condition of accessing these publications that users recognise and abide by the legal requirements associated with these rights.

\section{Take down policy}

The Research Portal is Queen's institutional repository that provides access to Queen's research output. Every effort has been made to ensure that content in the Research Portal does not infringe any person's rights, or applicable UK laws. If you discover content in the Research Portal that you believe breaches copyright or violates any law, please contact openaccess@qub.ac.uk. 
THE WOMAN TO THE PLOW AND THE MAN TO THE HEN-ROOST: WIVES, HUSBANDS AND

\section{BEST-SELLING BALLADS IN SEVENTEENTH-CENTURY ENGLAND}

By Christopher Marsh

READ: 22 SEPTEMBER 2017

A surprisingly strong case can be made for seeking the origins of English pop music not in the 1950 s, but in the 1590 s (or thereabouts). As the sixteenth century drew to a close, broadside ballads - single sheet songs that sold cheaply on the streets and covered a range of themes - were becoming big business in London and beyond. A Ditty Delightfull of mother watkins ale, for example, evidently set feet tapping up and down the country with its jaunty melody and its irresistible innuendo. ${ }^{1}$ Like many modern pop songs, its subject was sex, and the lines delivered by its male protagonist - 'For I will without faile/ Mayden, give you Watkins ale' - ensured that it stimulated moral outrage, again with modern parallels. One commentator called it a 'lascivious under song', while another marvelled that any self-respecting printer could issue 'such odious... ribauldrie as Watkins Ale'. This may also have been the song that was initially licensed for printing by the Stationers' Company as 'A ballad of a yonge man that went a wooying $\& c^{\prime}$ - but which was subsequently 'Cancelled out of the book, for the undecentnes of it in Diverse verses'. The imagined substance, Watkin's ale, was not, of course, a rejuvenating beverage but instead, to use the careful expression of the ballad scholar Tessa Watt, 'a bawdy allegory for the male

\footnotetext{
${ }^{1}$ A Ditty delightfull of mother watkins ale (?Abel Jeffs, c. 1592). All the ballads discussed in this article were printed in London. The tune can be found in Claude M. Simpson, The British Broadside Ballad and its Music (New Brunswick, 1966), 745.
} 
generative fluid'. ${ }^{2}$ The last decade of the sixteenth century also saw Thomas Deloney, a weaver turned wordsmith, churning out hit after hit in a compositional purple patch to rival that of Lennon and McCartney in the 1960s. ${ }^{3}$

In Deloney's time, the format of the ballad was evolving as the business developed, and by the 1620 s a standard broadside included a title, multiple verses, one or more woodcut pictures and the name of a recommended tune (musical notation was rarely included - instead, we have to find the melodies in books of instrumental pieces, dance tunes or songs). Tunes and pictures were regularly recycled, sometimes appearing on many different ballads, and most of the sheets - printed on poor quality paper - were used and displayed until they fell apart. We would know little of the genre, were it not for the activities of educated men such as John Selden and Samuel Pepys, who collected ballads and pasted them into volumes, thus preserving for posterity so many pieces of ephemera. ${ }^{4}$ Of course, early-modern balladry differed from modern pop music in many ways too. The cult of the celebrity artist and the notion of a definitive performance were absent, for example, and there were many more songs on public execution and the need for repentance than we typically see in the charts today. It can nevertheless be claimed that this was where English pop music - commercially driven, based in London and aiming at a mass audience - had its roots.

\footnotetext{
${ }^{2}$ Henry Chettle, Kind-Harts Dreame (London, 1593), C2r; Estienne de Maisonneufve, Gerileon of England. The second part (London, 1592), A4r; Hyder E. Rollins, An Analytical Index to the Ballad-Entries in the Registers of the Company of Stationers of London (Chapel Hill, 1924), no. 3058; Tessa Watt, Cheap Print and Popular Piety 1550-1640 (Cambridge, 1991), 67.

${ }^{3}$ On Deloney's songs, see Christopher Marsh, 'Best-Selling ballads and the Female Voices of Thomas Deloney', forthcoming in The Huntington Library Quarterly.

${ }^{4}$ On balladry in general, see: Natascha Würzbach, The Rise of the English Street Ballad, 1550-1650 (Cambridge, 1990); Watt, Cheap Print; Christopher Marsh, Music and Society in Early Modern England (Cambridge, 2010), chs. 5 and 6; Patricia Fumerton and Anita Guerrini (eds.), Ballads and Broadsides in Britain, 1500-1800 (Farnham, 2010); Angela McShane, 'Ballads and Broadsides', in Cheap Print in Britain and Ireland to 1660, ed. Joad Raymond (Oxford, 2011), 339-62; Broadside Ballads from the Pepys Collection ed. Patricia Fumerton (Tempe, Arizona, 2012).
} 
Wives, Husbands and Best-Selling Ballads

In most modern pop songs, the romantic characters are single and sexually-driven,

but marriage is scarcely mentioned. Early modern ballads, in contrast, tend to assume that marriage is part of the context: tales are told of single men and women who seek marriage and, crucially for this article, there are also many songs that feature married couples. These are topics of great interest to social historians, and early modern ballads - which are increasingly available in digital online facsimiles - have provided us with important and abundant source materials. ${ }^{5}$ There is not space to survey this work in detail here but it seems appropriate to draw attention at the outset to what is arguably a distorting tendency in much of the existing literature. In a nutshell, ballads are most frequently deployed in order to illustrate arguments about marriages that were threatened from within primarily by female failings: adulterous lust, subversive scolding and murderous intent. ${ }^{6}$ In some of the ballads favoured by scholars, vigorous husbands are commended for rising to the challenge, using violence against their insubordinate wives if necessary. In others, feeble men are mocked and castigated for a range of short-comings, including sexual inadequacy, jealousy and an inability to exert authority. Admirable wives are thin on the ground. Indeed, the content of ballads about courtship and marriage is often labelled misogynistic and

\footnotetext{
${ }^{5}$ See, in particular, http://ballads.bodleian.ox.ac.uk/ and http://ebba.english.ucsb.edu/ In this article, I will refer to the EBBA website regularly so that readers can view the ballads that cannot be displayed here. The quickest way to find a song is to type the EBBA number into the search box.

${ }^{6}$ See, for example: Laura Gowing, Domestic Dangers: Women, Words and Sex in Early Modern London (Oxford, 1996), 186-7, 207-08, 223; Stuart A. Kane, 'Wives with Knives: Early Modern Murder Ballads and the Transgressive Community', Criticism 38.2 (Winter, 1996), 219-37; Kirilka Stavreva, 'Scaffolds into Prints: Executing the Insubordinate Wife in the Ballad Trade of Early Modern England', Journal of Popular Culture 31.1 (Summer, 1997), 177-88, and Words Like Daggers: Violent Female Speech in Early Modern England (Lincoln, 2015), 46-8; Jacqueline Eales, Women in Early Modern England 1500-1700 (London, 1998), 31-2, 98; Barry Reay, Popular Cultures in England 1550-1750 (London, 1998), 24; Elizabeth A. Foyster, Manhood in Early Modern England: Honour, Sex and Marriage (London, 1999), 104, 111, 193-4; Bernard Capp, When Gossips Meet: Women, Family and Neighbourhood in Early Modern England (Oxford, 2003), 12-14; Martin Randall (ed.), Women and Murder in Early Modern News Pamphlets and Broadside Ballads, 1573-1697 (Aldershot, 2005); Simone Chess, " "And I my vowe did keepe": Oath Making, Subjectivity and Husband Murder in "murderous wife" ballads' in Ballads and broadsides, ed. Fumerton and Guerrini , 131-48; Frances E. Dolan, 'Tracking the Petty Traitor Across Genres', in Ballads and broadsides, ed. Fumerton and Guerrini , 149-72; Sarah F. Williams, Damnable Practices: Witches, Dangerous Women, and Music in Seventeenth-Century English Broadside Ballads (Farnham, 2015).
} 
interpreted as evidence of profound male anxiety. Historians highlight titles about tortured males - Cuckolds Haven: OR, The marry'd mans miserie, for example - and Anthony Fletcher has said about balladry, 'the creation of female gender here is confined to a familiar catalogue of vices that should be avoided or that men had it in their power to check'. ${ }^{7}$ Thus, wild wives and the challenge they posed to troubled husbands are considered to have been the dominant themes, and ballads about marriages in which the woman murdered the man have proved particularly appealing. There are some important exceptions - a more rounded account of ballad-marriages can, for example, be found in the work of Joy Wiltenburg, Sandra Clark and Eleanor Hubbard - but relationships endangered from within have certainly caught the imagination. ${ }^{8}$

There is an interpretative difficulty here. Historians pull from the existing balladcollections texts that suit their particular purposes, but in doing so they often create the impression that they are characterising marriage-ballads in general (and sometimes the argument is explicit). This matters: ballads were the most widely available form of print in the period - freely accessible even to the illiterate because they were so often performed and they therefore offer us insights into commonplace tastes and attitudes (though it is notoriously difficult to define these insights). ${ }^{9}$ If we get ballads wrong, the consequences for our understandings of early modern culture and society more generally may be significant.

\footnotetext{
${ }^{7}$ Cuckolds Haven (Francis Grove, 1638), EBBA 30036; Anthony Fletcher, Gender, Sex and Subordination in England 1500-1800 (New Haven, 1995), 117.

8 Joy Wiltenburg, Disorderly Women and Female Power in the Street Literature of Early Modern England and Germany (Charlottesville, 1992); Sandra Clark, 'The Broadside Ballad and the Woman's Voice', in Debating Gender in Early Modern England 1500-1700, ed. Christina Malcolmson and Mihoko Suzuki (Basingstoke, 2002), 103-20; Eleanor Hubbard, City Women. Money, Sex and the Social Order in Early Modern England (Oxford, 2012), 14-15, 112, 126-31.

${ }^{9}$ Arguably, we are still bedevilled by a wish to use ballads as representational 'mirrors' of social life. It surely makes more sense to regard them as an integral and influential feature of quotidian existence. Ballads were embedded and involved in early-modern lives, rather than being a set of black-and-white snapshots captured from above.
} 
Wives, Husbands and Best-Selling Ballads

Clearly, we need a methodology that is based on principles more sophisticated than lucky dip and source-mining.

For this reason, I am currently working with Angela McShane, the musicians of The Carnival Band and a number of invited singers to identify, record and display online 120 of the seventeenth century's most successful ballads. The aim is to select ballads not because they illustrate particular topics that interest us but because they were best-sellers in their own age. Sadly, there are no sales figures and the exercise is therefore challenging. We feel, however, that we have compiled as robust a list of hits as the evidence will allow, using the following indicators of popularity: the number of known editions of individual ballads and the distribution of these editions through time; the number of surviving copies of each song; evidence that publishers were keen to assert their copyright in specific titles (based on records kept by the Stationers' Company); the survival of songs beyond the seventeenth century, both in print and in vernacular tradition; and the capacity of songs to generate new names for existing tunes, a rough and ready sign of their success.

Our methodology aims to compensate for the inevitable privileging of songs that lasted many years by including criteria that allow more explosive but shorter-lived songs to qualify for inclusion. It also aims to balance the inevitable influence of the collectors by identifying indicators that instead reflect the broader priorities of the publishers. The limitations of the evidence mean that the results of this exercise are defensible rather than definitive, but there is no doubt that all of the selected songs were extraordinarily successful. When it comes to our efforts to understand these songs as historians, our distinctive emphasis is upon the integration of texts, tunes, pictures and performances. A somewhat restrictive 'lyrics-only' approach has characterised scholarly work on printed 
ballads for many decades, including much of what has so far been cited. Other recent work, however, attempts to develop a more holistic approach. ${ }^{10}$

The following pages will discuss a selection of these songs, concentrating in particular on those that feature marriage as a prominent theme. Roughly twenty-five of the 120 ballads fall into this category, and they can be used to address the following questions: how were husbands and wives represented in hit songs of the seventeenth century, and how might this representation encourage historians to re-think balladry and, perhaps, gender relations more widely? Let us begin with the simple observation that very few of our twenty-five hit songs have featured prominently in previous scholarly discussions of marital relations as represented in early-modern ballads. When historians choose their songs, these are not usually the songs they choose. ${ }^{11}$

Most of our songs do not, therefore, sit comfortably with the historiographical emphasis on ballad-marriages that were endangered by a challenging wife. Three might just about

\footnotetext{
${ }^{10}$ The 'lyrics only' approach informs many works, including Würzbach, Rise of the English Street Ballad, and Robin Ganev, Songs of Protest, Songs of Love: Popular Ballads in Eighteenth-Century Britain (Manchester, 2010). For more multi-media perspectives, see: Christopher Marsh, 'The Sound of Print in Early Modern England: the Broadside Ballad as Song', in The uses of script and print, 1300-1700, ed. Julia C. Crick and Alexandra Walsham (Cambridge, 2004), 171-90, and 'Best-Selling Ballads and their Pictures in SeventeenthCentury England', Past and Present, no. 233 (November, 2016), 53-99; Theodore Barrow, 'From "Easter Wedding' to "The Frantick Lover': the Repeated Woodcut and its Shifting Roles', in Studies in Ephemera: Text and Image in Eighteenth-Century Print, ed. Kevin D. Murphy and Sally O'Driscoll, (Lewisburg, 2013), 219-39; Alexandra Franklin, 'Making Sense of Broadside Ballad Illustrations in the Seventeenth and Eighteenth Centuries', in Studies in Ephemera, ed. Murphy and O'Driscoll, 169-93; Una Mcllvenna, 'The Power of Music: the Significance of Contrafactum in Execution Ballads', Past and Present 229.1 (2015), 47-89; Sarah F. Williams, Damnable Practices; Megan E. Palmer, 'Picturing Song Across Species: Broadside Ballads in Image and Word', Huntington Library Quarterly, 79.2 (Summer, 2016), 221-44.

${ }^{11}$ In the influential books by Anthony Fletcher, Elizabeth Foyster, Bernard Capp and Laura Gowing - all cited above - there are roughly 132 references to named ballads, only three of which appear on our full list of 120 hit songs (and all three are mentioned very briefly). Once again, an exception is Wiltenburg, Disorderly Women. This discusses several of our hit ballads, though they are not generally distinguished from other titles in terms of their immense popularity.
} 
qualify, and the strongest candidate among them was The lamentable fall of Queen Elenor, who for her Pride and wickedness by Gods judgements sunk into the ground at Charing-Cross and rose at Queen hive. This describes the cruelty and sinfulness of Edward I's queen, Eleanor of Castile, who, according to its narrative, committed numerous outrages, including the vile murder of the mayor of London's honest wife, and adultery with a friar. Eleanor clearly is a dangerous woman, and her husband the king is well-meaning but a little ineffectual. This is not, however, a ballad that says critical things of English marriages in general. Quite the opposite: Eleanor's wickedness is very clearly related to the fact that she is Spanish, and 'her spight to women-kind' is carefully noted. Thus, she is the enemy of her sex rather than its representative. Furthermore, the apparently exemplary marriage of the mayor and his wife, 'the London Lady good', suggests that healthy English relationships at all levels of society are threatened not by internal stresses but by the vanity and viciousness of a foreigner (sinister Spaniards were particularly appealing to English audiences when this song was originally composed, probably soon after the Armada of 1588). Appropriately enough, Queen Eleanor eventually loses her life after being swallowed mysteriously into the ground and then regurgitated several miles away. ${ }^{12}$

A further eight ballads are similar in that they bear some relation to the scholarly emphasis on wicked wives and harassed husbands, but in all cases there are unexpected subtleties and complications. We have, for example, the only title in our chart that portrays a woman who murders her husband - making it also one of the few that has already been

\footnotetext{
${ }^{12}$ The lamentable fall of Queen Elenor (1586-1625; F. Coles, T. Vere, and W. Gilbertson, 1658-64), EBBA 31939. The tune has not been found. Similarly troublesome women can be found in the hit songs $A$ Godly Warning for all Maidens (c. 1603; W. Thackeray and T. Passinger, 1686-8), EBBA 20238 and A good Wife, or none (c. 1624; Francis Coules, 1624-80), EBBA 30086.
} 
discussed by historians. ${ }^{13}$ The ballad, composed by Thomas Deloney in the 1590 s, is actually three songs in one, all set to a sombre and immensely popular tune, 'Fortune my foe', that had powerful associations both with romance and with the 'last dying speeches' of condemned killers. The first of the three songs on this sheet is entitled The Lamentation of Master Pages wife of Plimmouth. It tells the tale of Eulalia Page who, in 1590, was executed for the murder of her husband, along with her collaborating lover, George Strangwidge, and two hired killers. Singing from the heart and in her own voice - as channelled by the male author - Eulalia faces execution and describes her journey along a road to ruin. She begins,

Unhappy she whom fortune hath forlorne,

Despis'd of grace, that proffered grace did scorne,

My lawlesse love that lucklesse wrought my woe,

My discontent content did overthrow.

My loathed life too late I doe lament,

My hatefull deed with heart I doe repent:

A wife I was that wilful went awry,

And for that fault am here prepar'd to die. ${ }^{14}$

Thus far, the song fits the pattern that characterised most ballads about husbandkillers. In several respects, however, it is strikingly different from others on the same

\footnotetext{
${ }^{13}$ Randall, Women and Murder, xi-xii; Kane, 'Wives with Knives', 219; Stavreva, 'Scaffolds into Prints'; Foyster, Manhood, 105-06.

${ }^{14}$ The Lamentation of Master Page's wife of Plimmouth (c. 1590; H. Gosson, c. 1609), EBBA 20054. For the tune, see Simpson, British Broadside Ballad, 227. Excerpts from most of the ballads discussed in this paper were played in the lecture, some from our new recordings and some in live performance. A film of the lecture can be accessed at https://royalhistsoc.org/category/rhs-video-archive/
} 
theme. Eulalia is portrayed with considerable sympathy and is allowed the space to explain her conduct. She accepts the legitimacy of her punishment but explains that she was 'forced' into marriage by her greedy parents, her father in particular, and that she was already engaged to Strangwidge, her 'husband true'. The song also omits the kind of graphic detail about the murder and the execution that filled otherwise comparable ballads. And Eulalia is represented much more positively in the ballad than she was in a prose account of the same case. ${ }^{15}$ Even her acknowledged weakness is rooted in her romantic constancy. This is no cardboard cut-out of the husband-killing 'petty traitor' but in fact a surprisingly subtle and sophisticated account of one honest and loving woman's descent into criminality under the tragically-combined influence of true love and an oppressive father. It seems likely that the song's immense popularity was connected, at least in part, with its complex and uncategorical portrayal of the murderer whom it made famous. ${ }^{16}$ This raises interesting questions about the nature of its audience, a point to which we will return.

Other hit ballads in this sub-group of eight steer clear of murder but nevertheless follow a comparable line in representing with some sympathy wives who bring danger to their households. In Prides fall, a Dutch woman - married to a wealthy merchant - explains in graphic terms how her personal vanity led God to place in her womb a monstrous baby, designed as a warning to all 'fair dainty Dames' (figure 1). The baby's strange physical

\footnotetext{
${ }^{15}$ For general comments on the representation of female murderers, see: Frances E. Dolan, Dangerous Familiars. Representations of Domestic Crime in England, 1550-1700 (Ithaca, 1994), 49-50; Randall, Women and Murder, xiii; and Kane, 'Wives with Knives', 226-27. The contemporary pamphlet account of the case is in Sundrye strange and inhumaine Murthers, lately committed (London, 1591), B2r-B4v. In this version, Mistress Page is much more wicked, deceitful and culpable than she is in the ballad.

${ }^{16}$ Joy Wiltenburg has noted that successful murder ballads tended to 'invite intensive imaginative participation' by presenting vividly the 'inner turmoil' of the repentant criminal. See Wiltenburg, 'Ballads and the Emotional Life of Crime', in Fumerton and Guerrini, Ballads and Broadsides, 173-88.
} 
characteristics reflect the mother's vanity and both the woodcut artist and the wordsmith went to considerable and unusual pains in visualising a creature that scared all witnesses.

\author{
For it affrighted so \\ all the whole company, \\ That e're one said in heart, \\ 'vengeance now draweth nigh' \\ It had two faces strang[e], \\ and two heads painted fair, \\ On the brows curled locks, \\ such as our wantons ware [ie wear].
}

One hand held right the shape

of a fair looking-glasse,

In which I took delight

how my vain beauty was;

Right the shape of a Rod,

scourging me for my sin:

The other seem'd to have,

perfectly seen therein.

[place fig.1 (landscape) as close to this point as possible - it relates to text above and below] 
Wives, Husbands and Best-Selling Ballads

The baby dies, but not before delivering a stern - and remarkably precocious - warning to the astonished townsfolk. This is, then, a ballad about the dangers of female sinfulness the word 'wanton' is used repeatedly - and yet, as with Mistress Page, the wayward wife speaks for herself (as it were) and expresses her deep remorse. She turns her sin into something positive by seeking to influence other women, and the song ends with the lines, 'Maid and Wife, let my life,/ be warning to you all'. The tune is also distinctly upbeat and it was strongly connected by association with another hit ballad about a heroic male apprentice, a resonance that contributes a curiously positive vibe to Prides Fall. ${ }^{17}$ Of course, the anonymous song is probably a man's imagining of a female persona - it is difficult to escape such ventriloquism in the seventeenth century - but it is not a straightforwardly hostile representation of the Dutch wife. At the very least, she stands in the spotlight, delivering 98 lines of spoken text, only three of which mention her husband even in passing.

Other songs in this sub-group feature female adulterers but, once again, their portrayal in our hit ballads is rather different from the blunt and brutal representations of lascivious wives that have been highlighted in the scholarly literature. In The lamentable Ditty of Little Mousgrove, and the Lady Barnet, for example, an aristocratic wife, Lady Barnet, seduces an attractive local man, Little Mousgrove, luring him to her flower-strewn bower for an hour of passion (figure 2). Her husband learns of the assignation and bursts in upon the couple as they lie in bed. The denouement is bloody: Lord Barnet slays Little Mousgrove in a sword-fight, then kills his wife, and finally takes his own life. In the closing lines, we are warned about the consequences of lust, and yet the song - when heard in its

\footnotetext{
17 Prides fall: Or, A warning for all English Women (1585-1616; F. Coles, T. Vere and J. Wright, 1663-74), EBBA 31879; The Honour of a London Prentice (c. 1580-1600; W. Thackeray and T. Passinger, 1686-88), EBBA 21266. The latter ballad was probably an Elizabethan composition. The melody can be found in various early-modern sources, ranging from sixteenth-century instrumental collections to eighteenth-century song books (see Simpson, British Broadside Ballad, 14).
} 
Wives, Husbands and Best-Selling Ballads

entirety - certainly does not feel like a fierce condemnation of a wicked wife. Even in the moralising final verse, Lady Barnet is described as a 'worthy wight', and the multiple deaths that occur are more like the climax of a tragic love story than an account of sin and its foulsmelling fruits. ${ }^{18}$ The pictures, as so often, are recycled from other sources. On the right, for example, a commonly encountered soldier represents the angry Lord Barnet as he approaches a bed-scene that also began life elsewhere (viewers must make their own sense of the fact that the Lady and her lover appear to be sharing those precious post-coital moments with some visiting clerics).

[place figs. $2 \mathrm{~A}$ and $2 \mathrm{~B}$ (if possible, side by side in portrait to form a single image) as close to this point as possible - it relates to the paragraph above]

The lamentable Ditty shares one of its pictures with our next song, A new Ballad of the Souldier and Peggy (figure 3). There were several editions of this ballad in the second half of the seventeenth century, and its lovely lilting melody - described on the sheet as 'a new Northerne Tune' - subsequently became known as 'Peg and the soldier'. ${ }^{19}$ The song tells the story of another female adulterer who places her marriage in jeopardy, but its conclusion sets it apart from many more merciless accounts of such characters. Peggy has a baby at home but she nevertheless runs off willingly to Ireland with a seductive soldier. Her 'good husband' is understandably distraught when he realises that Peggy has sailed away on

18 The lamentable Ditty of Little Mousgrove (H. Gosson, c. 1630), EBBA 20172. Folksong versions of this narrative were regularly collected in twentieth-century America where it was known under various names, including 'Little Matty Grove'. The original tune is lost.

${ }^{19}$ A new Ballad of the Souldier and Peggy (F. Coules, c. 1640), EBBA 30250. For the tune, see Simpson, British Broadside Ballad, 572. 
a lustful impulse. After hiring a nurse to feed the baby, he expresses his anger but chooses other targets than his wife:

\author{
He cursed the Carpenter \\ that made the ship, \\ And eke the Plummer, \\ for plumming so deepe: \\ he banned the wind \\ and the water so cleere, \\ That carried her over sea \\ with a souldier.
}

When life on the road proves a disappointment to Peggy, she returns home and begs forgiveness. Her husband, remarkably, welcomes her back immediately, asking only that she promise not to stray again.

[place figs. $3 \mathrm{~A}$ and $3 \mathrm{~B}$ (if possible, side by side in portrait to form a single image) as close to this point as possible - it relates to the text above and below]

Although Peggy is at fault - she is a 'wanton lewd woman' - she is also treated rather generously, both by her husband and by the narrator. We might expect a more savage act of judgement, like the one at the climax of the 'Little Mousegrove' ballad. Instead, Peggy's waywardness is presented as almost excusable - 'For youth it is wanton/ and will have a fling' - so long as the lesson is learned, 'And Peggy is at home with her 
husband againe'. The mood of the tune contributes to the 'all's well that ends well' tone, and the recycled pictures track the narrative in a rudimentary manner. On the left, we see the soldier who, having represented Lord Barnet on the previous ballad, now stands beside an interesting illustration of a woman with a sword at her side. This image also appeared subsequently on a song - popular but not quite one of our hits - about the female soldier, Mary Ambree, who brought England glory with the great deeds she performed in the Netherlands. Clearly, she carried an association with soldiering from one ballad to the next (more mysteriously, however, Mary Ambree has apparently mislaid the sword). ${ }^{20}$ On the song about Peggy, two woodcuts on the right complete the tale. Here, she is no longer the bold young woman running off with a soldier but instead the conventional wife who stands beside her happy husband (everybody had seen both of these pictures dozens of times). The assumptions that underlie the ballad are, of course, conventionally patriarchal - the wife goes astray, and her deliverance consists in returning to live with a husband who forgives her as God forgives him - but this song can hardly be said to express the 'crude if jocular misogyny' that Bernard Capp and others have found to be characteristic of the cheaper forms of print in general. ${ }^{21}$

The fourteen ballads that complete our collection of marital mega-songs carry us even further from this emphasis, suggesting that the role of balladry within early-modern debates about marriage and gender relations more generally may have been misunderstood. Some of these ballads idealise marriage and present to the listener wives

\footnotetext{
${ }^{20}$ The valorous Acts performed at Gaunt, By the brave bonny Lasse Mary Ambre (William Gilbertson, 164765 ?), EBBA 36066. Successful woodblocks were often altered and copied; the difference between the two pictures is not, therefore, unusual.

${ }^{21}$ Bernard Capp, When Gossips Meet, 12. The other ballads in this sub-group of eight are: The Woful Lamentation of Mistris Jane Shore (c. 1624; F. Coles, T. Vere and J. Wright, 1663-74), EBBA 32019; A Lamentable Ballad of Fair Rosamond (c. 1593; W. Thackeray and T. Passinger, 1686-8), EBBA 20235; A New little Northren Song (H. G., c. 1631), EBBA 20122; An excellent Ballad of the Mercer's Son of Midhurst (c. 1624; J. Clarke, W. Thackeray and T. Passinger, 1684-6), EBBA 20258.
} 
Wives, Husbands and Best-Selling Ballads

and husbands who live together in love and happiness. The Happy Husbandman: OR, Country Innocence, for example, opens with the lines,

MY young Mary do's mind the Dairy,

while I go a Howing, and Mowing each Morn;

Then hey the little Spinning Wheel

Merrily round do's Reel

while I am singing amidst the Corn:

Cream and Kisses both are my Delight

She gives me them, and the Joys of Night;

She's soft as the Air,

As Morning fair,

Is not such a Maid a most pleasing Sight?

While I whistle, she from the Thistle

does gather Down, for to make us a Bed,

And then my little Love does lie

All the Night long and dye

in the kind Arms of her nown dear Ned ;

There I taste of a delicate Spring,

But I mun not tell you nor name the thing,

To put you a Wishing,

And think of Kissing,

For Kisses cause sighs, and young Men shou'd sing. 
The song is almost nauseating in its portrayal of an idyllic rural marriage in which the spouses perform their distinct but complementary roles with a coy smile on their faces and a sentimental song in their hearts. Their lives are full of love-making but devoid of troublemaking (wisely, they leave politics to others). This feels, of course, like a town Tory's imagining of country life, and we are told that London wives are greedy and domineering in comparison to the paragon described here. It is difficult at first to see why this song was so popular, but if we listen as well as look, then some sense of its appeal can be recaptured. The melody, described on the sheet as 'a pleasant new Court Tune', is beautiful, capable perhaps of conjuring something sublime from something ridiculous. ${ }^{22}$

Most of our remaining songs are different in that they do demonstrate an acute awareness of the dangers to marriage but, crucially, these dangers are typically the work of forces external to the relationship rather than the result of tensions between husband and wife. Frequently, marriages are threatened or complicated by the disapproval of parents or relatives, and the ballad-makers' sympathies are invariably with the couple rather than their critics. One ballad, printed repeatedly during the seventeenth century, bore the title, $A$ constant Wife, a kinde Wife, A loving Wife, and a fine Wife, Which gives content unto mans life. In several editions, the repeated capital Ws in the title make the point that finding a worthy woman to wed is the song's principal focus. Written in the man's voice, the first half of the ballad describes the battle he fought to free his beloved from the evil clutches of her disapproving family ('She likely was for to be rich,/ and I a man but meanely'). He smashes

\footnotetext{
${ }^{22}$ The Happy Husbandman: OR, Country Innocence (P. Brooksby, 1685-8), EBBA 21041. The tune was composed for the ballad and can be found in Simpson, British Broadside Ballad, 502. For other generally positive representations of marital relationships in our group of hit ballads, see: $A$ pleasant Song of the Valiant Deeds of Chivalry (c. 1592; F. Coles, T. Vere, J. Wright and J. Clarke, 1674-79), EBBA 30400; A pleasant new Ballad of the Miller of Mansfield (c. 1588; E. Wright, 1611-56), EBBA 30162; The Shepherd and the King (c. 1578; A. M., 1686-93), EBBA 32009.
} 
his way into her uncle's house, rescues his sweetheart and marries her without the consent of her family - and he urges other men to adopt a similarly belligerent attitude to the enemies of true love. In calmer mood, he then devotes the second half of the song to praising his new wife, commending her physical beauty, her virtue, her wisdom and her obedience. The woman in this song, though set at its centre, is a passive figure, a desirable trophy over which men fight, but she is nothing like an adulterous scold. ${ }^{23}$

The woman featured in A worthy example of a vertuous wife was a far more active presence. The song was popular in England from the 1590s right through into the eighteenth century. It tells the story of a woman from ancient Rome who, having married against her father's will, grasps the opportunity to achieve reconciliation with him after he is imprisoned and starved by the emperor. And where the man in our previous ballad uses his fists to effect a rescue, the heroine of this song must deploy more subtle and feminine means. To cut a long story short, she tricks the authorities into allowing her access to the old man, and then keeps him alive by secretly breast-feeding him through the bars of his cell every day for a year (he 'was most faire and fat to see,/ yet no man knew which way'). The Emperor eventually realises what has happened and, impressed by such virtuous devotion, pardons the prisoner and rewards his daughter with 'great preferments'. ${ }^{24}$ The song acknowledges no sources but it is clearly based on ancient Roman stories recorded by Valerius Maximus and Pliny the Elder as examples of familial devotion. Valerius Maximus told two similar tales, and the one that he developed most fully actually featured an imprisoned mother rather than a father. Pliny, interestingly, recorded only this all-female

\footnotetext{
${ }^{23}$ A constant Wife, a kinde Wife (F. C., c. 1631), EBBA 20181. For the tune, see Simpson, British Broadside Ballad, 445. See also An excellent Ballad of a Prince of Englands Courtship to the King of France's Daughter (1585-1616; Alex. Milbourn, 1686-93), EBBA 30068.

${ }^{24} A$ worthy example of a vertuous wife, who fed her father with her own milk (c.1596; E. W, c. 1635), EBBA 30398.
} 
version. By the sixteenth century, however, a single narrative about Cimon (the father) and Pero (the daughter) was firmly in fashion, and it subsequently became known as 'Roman charity'. It appears that early-modern minds preferred the version in which a woman fed a man, perhaps because this intensified the incestuous frisson and reflected the topical complexities of patriarchy-in-practice..$^{25}$

There are several interesting points to be made about this hit song. Its focus is not actually her marital relationship, except indirectly, and yet the title and the final verse highlight her status as a 'vertuous' and 'loving' wife. The story is really about her conduct as a daughter, and the insistence upon her wifeliness at the song's top and tail perhaps has the effect of tying different types of female dependence and obligation together. Ballads about active women - transvestite soldiers, for example - very often conclude with verses about marriage, in which convention reclaims those who might seem to have threatened it. This is necessary here too, for the men in this song are not impressive: her father is pathetic, the emperor is autocratic, and the husband hardly features. The 'vertuous wife' is a feisty, resourceful and active woman who stars in her own show. She has previously defied her father, and now she defies the emperor - labelling him a 'tyrant' - and tricks his guards. She deploys traditional womanly wiles - 'wringing hands and bitter teares' - in order to do good and get her way. She also displays more clearly admirable feminine qualities such as selflessness, and the instruments through which these qualities are revealed - her own breasts - could hardly be more conventional in their symbolism. She is a complex creation, clearly set up for our admiration, and the tune - strongly associated with a heroic male

\footnotetext{
${ }^{25}$ See Valerius Maximus, Memorable Doings and Sayings, transl. and ed. D. R. Shackleton Bailey, 2 vols. (Cambridge, Mass., 2000), vol. I, 501; Pliny. Natural History, transl. and ed. H. Rackham, 10 vols. (London and Cambridge, Mass., 1938-1962), vol. II (1942), 587. The pivotal scene in this tale was painted during the earlymodern period by Rubens, Caravaggio and many others.
} 
Wives, Husbands and Best-Selling Ballads

ballad about the medieval battle at Chevy Chase - adds to the positive atmosphere. ${ }^{26}$ We cannot know who bought this ballad, nor why it was so successful, but we might speculate that this virtuous wife worked her way, in exaggerated and exoticised guise, through the daily dilemma that faced many early-modern English wives: how to find fulfilment within patriarchy through the somewhat paradoxical or counter-intuitive project of making it their own. The ballad was simultaneously a fantastical escape from 'reality' and a sturdy tool with which to work on it.

It is perhaps difficult to reconcile the popularity of the woman who fed her father with the undoubted appeal of Thomas Deloney's Excellent Ballad of Patient Grissel. In this version of an old story previously told by Boccaccio, Petrarch and Chaucer, a marquis marries a beautiful but poor woman called Grissel, and soon faces murmuring criticism from his noble advisers for marrying so far beneath him. He loves Grissel truly, but resolves that he must prove her moral worth to the doubters by subjecting her to a terrible series of ordeals. He removes her children, telling her (falsely) that he has had them killed, and he banishes her back to her father's miserable cottage. Grissel bears it all with patience and constancy, obeying each of her husband's outrageous commands until, finally, he reunites her with her children and explains that she has now passed all the necessary tests. ${ }^{27}$ It is an unsettling ballad, and very different in its portrayal of the featured wife from the song we have just considered. Its appeal to men is obvious enough, but the reasons why women might have felt drawn to it, perhaps cherishing it alongside their copies of $A$ worthy example

\footnotetext{
${ }^{26}$ A memorable Song on the unhappy hunting in Chevy-Chase (c. 1624; F. Coles, T. Vere and J. Wright, 166374), EBBA 30408. The tune was one of the most popular of the period (see Simpson, British Broadside Ballad, 97).

${ }^{27}$ An Excellent Ballad of Patient Grissel (c. 1624; F. Coles, T. Vere, and W. Gilbertson, 1658-64), EBBA 31768. The tune is lost. On this and other representations of Grissel in the period, see Judith Bronfman, 'Griselda, Renaissance Woman', in The Renaissance Englishwoman in Print. Counterbalancing the Canon, ed. Anne M. Haselkorn and Betty S. Travitsky (Amherst, 1990), 211-23.
} 
Wives, Husbands and Best-Selling Ballads

of a vertuous wife, are harder to fathom. Chaucer had argued forcefully that no wife could be expected to copy Grissel, but the author of a seventeenth-century chapbook about her, taking issue with those who complained about 'the absurdity of the example', urged that this is exactly what women should do. ${ }^{28}$ Arguably, it was possible to admire Grissel not primarily for her obedience but instead for her refusal to buckle under unimaginable pressure from a cruel husband. Within this view, her extreme passivity becomes almost a species of defiant action, and - like the woman who fed her father - she survives and eventually thrives. Of course, there is a fine line between admiring obedience and admiring the capacity to suffer without complaint, but the genius of Deloney resided, arguably, in his ability to devise songs that appealed to men and women simultaneously but for different reasons. Such songs clearly stimulated debate, and the ballad 'Of Patient Grissel' was said to be a favourite choice for display on the walls of country homes. ${ }^{29}$

In our last ballads, marriages are endangered not by disapproving observers but by a range of other circumstances, none of which has anything to do with stresses within the core relationship. Indeed, most of the marriages are strong and loving, exemplary even, but assaulted from outside. There is one about Catherine Willoughby, Duchess of Suffolk, who fled England with her husband and baby during the 1550s in order to escape persecution for her godly Protestantism. Another introduces us to a more humble bride, who dies suddenly on her wedding day after dispensing godly and practical advice to her husband and friends (she sensibly suggests that they hire a carpenter to turn her marital bed into a coffin). In both songs, the wives take centre-stage, their courageous conduct praised and promoted. They are often surrounded by men and conventional in their femininity, but they shine

\footnotetext{
${ }^{28}$ Geoffrey Chaucer, The Canterbury Tales, ed. Jill Mann (London, 2005), 336; The ANCIENT, True, and Admirable History of Patient Grisel (London, 1619), C4v.

${ }^{29}$ So said Sir Robert Cotton, quoted in Hyder Rollins, 'The Black-Letter Broadside Ballad', Publications of the Modern Language Association of America, 34 (1919), 336.
} 
Wives, Husbands and Best-Selling Ballads

nonetheless. ${ }^{30}$ The same is true of The Constancy of Susanna, which recounts the famous

Biblical tale: Susanna, wife of Joachim, is forced to take a stand against two lecherous elders

of Babylon who first make a pass at her, and then, angered by her resistance, accuse her

falsely of committing adultery with another man. ${ }^{31}$ The opening verses run,

There was a man in Babylon,

of reputation great by fame:

He took to wife a fair woman

Susanna was she cal'd by name:

A woman fair and vertuous,

Lady, Lady,

Why should not we of her learn thus,

To live godly.

Vertuously her life she led,

she feared God, she stood in awe,

As in the story you may read,

was well brought up in Moses Law,

Her parents they were godly folk,

Lady, Lady,

\footnotetext{
${ }^{30}$ The most Rare and Excellent History, Of the Dutchess of Suffolks Callamity (c. 1592; F. Coles, T. Vere and J. Wright, 1663-74), EBBA 31743; The Brides Buriall (c. 1603; H. G., c. 1635), EBBA 30586. The tunes can be found in Simpson, British Broadside Ballad, on 588 and 368 respectively. See also $A$ Lamentable ballad of the tragical end of a Gallant Lord (c. 1570; F. Coles, T. Vere and W. Gilbertson, 1658-64?). EBBA 31955, and A most excellent Ballad, of an old man and his wife (E. [A.], 1620), EBBA 20028.

${ }^{31}$ An Excellent Ballad, intituled, The Constancy of SUSANNA (c. 1562; W. Thackeray, J. Millet and A. Milbourn, 1689-92?), EBBA 33840. Constancy was a key virtue for ballad-women and, intriguingly, our 120 hits songs were much more likely to include the word 'constant' and/or related terms than were ballads in general. 'Constance' was also a fashionable girl's name in England during the seventeenth century, fading away in the decades after 1700 (https://www.ancestry.co.uk/) .
} 
Why should we not then talk

Of this Lady.

The ballad-writer, working in the late sixteenth century, begins with a man of high status - Joachim - but then quickly abandons him in favour of his much more interesting wife. The author feels the need to justify his decision - 'Why should not we of her learn thus, to live godly'? - but it was clearly a good one, and Susanna sold for centuries. Two hundred years after the ballad was composed, a Welsh fiddler, Alawon John Thomas, wrote into his notebook a tune called 'Susannah' which is recognizably a version of the Elizabethan melody. ${ }^{32}$ The original ballad has Susanna at its heart, and the refrain -'Lady, lady' - keeps her there, even when Daniel, sent by God, arrives to save her at the end. ${ }^{33}$ Of course, it can be argued that Susanna's appeal lay partly in her capacity to titillate men - the woodcuts used by printers in the seventeenth century came to follow the greater artworks of the age in concentrating on the moment of attempted seduction and depicting Susanna as almost nude - but this was surely not enough to carry her song up the charts. ${ }^{34}$ However we look at her, however we listen to her, Susanna is a long, long way from the scolding and lascivious wives who have tended to dominate the literature on balladry and gender.

Our final song is a little closer to the conventional view of ballad-marriages in that it discusses a relationship that is endangered by a difference of opinion between the wife and

\footnotetext{
${ }^{32}$ A Fiddler's Tune Book from Eighteenth-Century Wales, ed. Cass Meurig (Aberystwyth, 2004), 127. I am grateful to Judith Marsh for bringing this source to my attention. For another version of the melody, see Simpson, British Broadside Ballad, 412. This interesting tune was Elizabethan and originally had romantic associations as a result of its connection with Elderton's song, The panges of love. Arguably, the ballad about Susanna was an unusually successful attempt to redirect these associations towards something more godly.

${ }^{33}$ This refrain also appears in the earlier ballad by Elderton (it was clearly the 'hook' in both songs, and playwrights regularly made reference to it).

${ }^{34}$ Compare the various editions that are included at http://ebba.english.ucsb.edu/ Artists who depicted Susanna and the elders included Ruben, Van Dyk and Rembrandt. The scene was also used regularly in domestic wall-paintings, and many representations are listed in auction catalogues of the period.
} 
the husband. It will help to draw strings together and matters to a close. Martin Parker's The Woman to the Plow and the Man to the Hen Roost was printed repeatedly after its first appearance during the 1620 s (figure 4). Its status as a hit is also suggested by the survival of closely related narratives in later folk-song and by the prominent inclusion of its title in a fascinating medley - a coloured drawing that creates the illusion of an overlapping pile of printed papers - devised by Samuel Moore in the early eighteenth century. ${ }^{35}$ In the song, a married couple criticise one another's work and decide to swap tasks, with results that are as disastrous as they are predictable:

As he to Churn the Butter went,

One morning with a good intent,

The Cot-quean fool did surely dream,

For he had quite forgot the Cream,

He churned all day, with all his might, And yet he could get no Butter at night...

And shortly after on a day,

As she came home with a load of Hay,

She overthrew it, nay and worse,

She broke the Cart, and killd a Horse,

The good-man the same time had ill luck,

He let in the Sow, and she kil'd a Duck.

\footnotetext{
35 The Woman to the PLOW; And the Man to the HEN-ROOST (F. Grove, c. 1629), EBBA 32024. Several versions of the tale, under names such as 'Father Grumble' and 'Old Dorrington', can be found by searching the various databases available at https://www.vwml.org/vwml-home I am grateful to Tim Somers for bringing the medley to my attention: Samuel Moore, Medley (c. 1700), Victoria and Albert Museum, E.128-1944.
} 
Here, there are clear points of contact with the types of ballad that have previously been highlighted by historians. Conflict is at its heart, as husband and wife clash over their proper economic roles and spheres of influence. The sexual inadequacy of the husband is not mentioned explicitly but it is alluded to in the label 'cot-quean' - a man who busies himself with women's matters - and emphasised more strongly in a little woodcut of the man with horns. After its appearance here, this picture became one of the stock images for ballads about cuckoldry in the decades that followed. ${ }^{36}$ On The Woman to the Plow, the picture implies that the husband can expect to be cuckolded, and probably that he deserves it, even if it has not happened yet. He is argumentative, calling his wife a 'whore' at the outset, but his empty masculine bluster merely masks his foolishness, and at the end he has no choice but to back down.

[place fig. 4 as close to this point as possible - it relates to the text above and below]

In other ways, however, this ballad - like most of the songs mentioned above distinguishes itself from those typically highlighted by historians (and let us remember that this one was a major hit in its own time). We could not, for example, call it misogynistic or even desperately anxious, nor could we characterise it as obsessed with the notorious female vices. ${ }^{37}$ Indeed, the wife is scarcely criticised at all and, by the end, the author's sympathies clearly lie with her (the pictures chosen to represent her are, by prior association, also more solidly positive than the male woodcuts). The subtitle implies that

\footnotetext{
${ }^{36}$ See, for example, THE Hen-peckt CUCKOLD: OR, The Cross-grain'd Wife (J. Millet, 1685?), EBBA 21793.

${ }^{37}$ Anthony Fletcher detects 'a misogynist streak' in ballads on male and female work but does not mention this extremely popular song (Fletcher, Gender, Sex and Subordination, 230).
} 
she must 'cure' her cotquean-husband, and she does so primarily by tolerating his misguided intervention until he realises his mistake. And while the husband is scorned, he does nevertheless find his way out of the thicket in which he has entangled himself. The marriage is in trouble but the problem is eventually solved; we can therefore see this as a companionate relationship in which wife and husband, working together by working apart, prove capable of managing their difficulties (of course, there is now plenty of work to suggest that the 'separate spheres' model deployed in the ballad bore only a passing resemblance to the daily experiences of most people)..$^{38}$ The role models are eventually and essentially positive, as in most of the ballads surveyed above, and these super-successful songs display a notable preoccupation with the resolution of crisis through interpersonal reconciliation. The fact that the female role model in this particular ballad is the more positive of the two may tell us something about the core audience for the song. Although it begins, 'Both Men and Women listen well', there is a sense in which Parker appears to aim particularly at female consumers, allowing and encouraging them to laugh at their interfering husbands. Female and male labour are accorded equal value, and it is the wife who earns praise for quietly sorting out her foolish man. Other wives with interfering husbands are advised 'To serve them as this Woman did' (there is a nice ambiguity to the term 'serve' here). Perhaps the title of the lost tune provides another clue: 'I have for all good wives a song'.

This suggestion deserves development. We have very little concrete evidence about gendered patterns of ballad-consumption, and all propositions must therefore be tentative,

\footnotetext{
${ }^{38}$ See, for example: Amanda Flather, Gender and Space in Early Modern England (Woodbridge, 2007), 43-50, and 'Space, Place and Gender: the Sexual and Spatial Division of Labour in the Early-Modern Household', History and Theory, 52 (October, 2013), 344-60; Gowing, Domestic dangers, 5-6, 26, and " "The Freedom of the Streets": Women and Social Space, 1560-1640', in Londinopolis. Essays in the cultural and social history of early-modern London, ed. Paul Griffiths and Mark S. R. Jenner (Manchester, 2000), 134-5, 1378.
} 
but it does seem probable that many of the ballads discussed above were aimed primarily at and consumed primarily by women. There is anecdotal literary evidence to suggest that women loved ballads, perhaps even more than men did. As early as 1584 , the publisher of a collection of ballads assured potential readers, 'Here may you have such pretie thinges,/ as women much desire'. Ballads, said John Earle a few decades later, were 'chanted from market to market, to a vile tune and a worse throat; whilst the poor country wench melts like her butter to hear them' ${ }^{39}$ Women were sometimes said to have a particular taste for love-ballads. We might be tempted to dismiss this as a male slur designed to imply female frivolity, but Margaret Cavendish agreed, commenting in one letter that ballads were properly the music of spinsters and housewives in company on a winter evening. Other evidence suggests the role played by women in selling ballads. ${ }^{40}$ Furthermore, references within our twenty-five songs seem to suggest that the ballad-makers, most of whom were male, often had female consumers firmly in mind. The songs contain 40 direct appeals to either women or men, and three-quarters of these favour females: ballads are aimed at 'dainty dames', 'You maidens', 'English women', 'maid and wife' and so on. Of the 18 titles that highlight either male or female characters, 14 choose women and only 4 pick men. And ballad-makers were also far more willing than we might have imagined to flatter female characters: the ten adjectives applied most frequently to women in our twenty-five hit marriage ballads included 'fair', 'comely', 'sweet', 'bright', 'good' and 'virtuous', and only

\footnotetext{
${ }^{39}$ Clement Robinson, A Handfull of pleasant delites (London, 1584), A1r; John Earle, Micro-cosmographie (London, 1628), B61. Several suggestive sources are gathered together in Würzbach, Rise of the English Street Ballad, 263-4, 266, 275, 278, 279, 280-2. On female consumers of balladry, see also: Sarah F. Williams, 'Witches, Lamenting Women, and Cautionary Tales: Tracing 'The Ladies Fall' in Early Modern English Broadside Balladry and Song', in Gender and Song in Early Modern England, ed. Leslie C. Dunn and Katherine R. Larson (Farnham, 2014), 31-46; Clark, 'The Broadside Ballad and the Woman's Voice'; Pamela Brown, Better a Shrew than a Sheep. Women, Drama and the Culture of Jest in Early-Modern England (Ithaca, 2003), 90.

40 Margaret Cavendish, CCXI Sociable Letters (London, 1664), 429. See also Clark, 'Broadside ballads and the Woman's Voice', 103. The female ballad-singers who feature regularly in the artistic output of William Hogarth are discussed in Elizabeth Kathleen Mitchell, 'William Hogarth's Pregnant Ballad Sellers and the Engraver's Matrix', in Ballads and Broadsides, ed. Fumerton and Guerrini, 229-50.
} 
one term - 'wanton' - was clearly pejorative (and 13 of its 17 appearances occurred in a single song). ${ }^{41}$ This begins to look rather like a negotiation between male didacticism and female taste, with female taste more than holding its own. It calls to mind the evidence assembled by Jacqueline Pearson to show how female theatre-goers influenced the content of male-authored plays in the later seventeenth century. ${ }^{42}$ In the case of balladry, there emerges from the negotiation a set of songs that emphasise the female side of marriage, presenting wives whose conventional femininity is either strong, spirited and admirable or wayward but deserving of sympathy. Male authors and publishers - promoters of 'transvestite ventriloquism', to use Elizabeth Harvey's phrase - were, of course, aiming to shape female opin ion, but if they wanted to make money they also needed to let female opinion shape their products. ${ }^{43}$ We might note, in passing, a wealth of theoretical work on 'active audiences' for modern pop music and other cultural forms. As consumers, we are capable of making products our own not just by purchasing them but by doing our own thing with them once they are in our hands or our heads; we can receive, re-jig or reject the messages towards which the creators may have aimed to guide us. ${ }^{44}$

It seems certain that these ballads were successful partly because they allowed and encouraged women to take them on, take them over and breathe new life into them. All sorts of escapes into fantasy-worlds were possible through reading and singing, and all sorts

\footnotetext{
41 The Woful Lamentation of Mistris Jane Shore.

42 Jacqueline Pearson, The Prostituted Muse: Images of Women and Women Dramatists 1642-1737 (New York, 1988), 33-41.

${ }^{43}$ Elizabeth D. Harvey, Ventriloquized voices. Feminist theory and English Renaissance texts (London, 1992), 1, 16.

${ }^{44}$ There is a useful overview in Keith Negus, Popular Music in Theory (Cambridge, 1996), ch. 1. See also David Morley, 'Active Audience Theory. Pendulums and Pitfalls', Journal of Communication, 43.4 (1993), 13-19; The Audience Studies Reader, ed. Will Brooker and Deborah Jermyn (London, 2003); Jim Huimin, 'British Cultural Studies, Active Audiences and the Status of Cultural Theory', Theory, Culture and Society, 28.4 (July 2011), 12444.
} 
Wives, Husbands and Best-Selling Ballads

of personal re-imaginings too. The woman who inhabited one of our ballads could pass comment, discreetly, on her own marriage and the marriages of others, or she could travel as far from her own daily life as possible. These possibilities fit well with recent work emphasising the influence of female singers over the content of Thomas Campion's ayres and the importance of women's musical voices more generally. ${ }^{45}$ Judith Bennett has used late-medieval song to argue that it helped women to 'negotiate the contradictions and complexities of... patriarchy'. Katie Barclay, writing about early nineteenth-century Scotland, has shown how the ballad-repertoires of female singers differed from those of their male counterparts, partly because men and women memorised contrasting verses from the same song, resulting in versions that had distinctive and gendered emphases. ${ }^{46}$ Throughout these centuries, women somehow found their voices through the words of men, and male composers knew that it made good sense to facilitate this process. In the estimation of Sandra Clark, ballad-writers in particular were 'as concerned to address women's concerns as men's'. ${ }^{47}$

Other categories of early-modern ballads may have catered more to male audiences. The most clearly political of our hit ballads, for example, seem to mention women much less frequently and much less positively than the marriage ballads. ${ }^{48}$ We might also need to include within the 'predominantly male' category, those ballads - highlighted by historians

\footnotetext{
${ }^{45}$ Scott Trudell, 'Performing Women in English Books of Ayres', in Gender and Song in Early Modern England, ed. Leslie C. Dunn and Katherine R. Larson (Farnham, 2014), 15-29; Thomasin LaMay (ed.), Musical Voices of Early Modern Women. Many-Headed Melodies (Farnham, 2005); Lynda Phyllis Austern, 'Women's Musical Voices in Sixteenth-Century England', Early Modern Women, 3 (2008), 127-52.

${ }^{46}$ Judith M. Bennett, 'Ventriloquisms. When Maidens Speak in English Songs, c. 1300-1550', in Medieval Woman's Song. Cross-Cultural Approaches, ed. Anne L. Klinck and Ann Marie Rasmussen (Philadelphia, 2002), 201; Katie Barclay, " 'And Four years space, being man and wife, they Loveingly agreed': Balladry and the Early Modern Understandings of Marriage," in Finding the Family in Medieval and Early Modern Scotland, ed. Elizabeth Ewan and Janay Nugent (Aldershot, 2008), 30-3.

${ }^{47}$ Clark, 'The Broadside Ballad and the Woman's Voice', 110.

48 There are no women, for example, in the immensely successful song, Win at First, Lose at Last: Or, A New game at CARDS (1660; F. Cole, T. Vere, J. Wright, J. Clark and T Passinger, c. 1682), EBBA 20818.
} 
Wives, Husbands and Best-Selling Ballads

and mentioned at the outset - in which wives are sexually-driven, power-hungry scolds and husbands are under pressure to assert their authority. There were many such ballads but, a little strangely, they hardly feature on our list. This too may imply the economic power of the female consumer, and it suggests that the time has come for historians of balladry and marriage to think less about Cuckolds Haven and more about The Constancy of Susanna. Just for the record, there is one extant copy of the former but sixteen of the latter. 